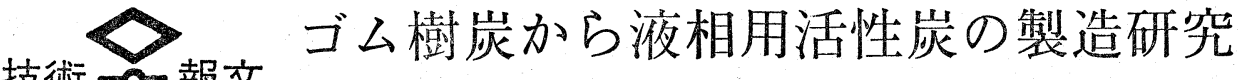 \\ -1981.2 .25 受理一
}

大平洋金属(侏) 廣 瀬 正 巴*，川和田邦男**

青木宏之蛋

日本大学 柳井 弘***

\section{1. 緒言}

活性炭製造用の原料としては，植物系の木材，のこ くず，ヤシ殼，パルプ廃液などの㴗かに鉱物系の石 炭, 石炭残渣, 石油コークス, 石油ピッチなどが使用 されるが, 工業的には活性化の難易, 原料の品質, 価 格, 大量に入手可能かどうかなどの諸点が原料選定の 条件となる。

筆者らは, マレーシア拉よびインドネシアのゴム材

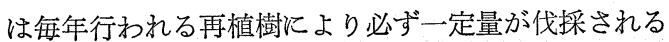
こと, 平坦地作業で集荷輸送が容易なことなどの諸点 から炭材としての条件を備兄ていることに着目した。 そこで1972年にインドネシアのスマトラ島メダン地区 に木炭工場を建設してビーハイブ型炭化忓を設置し, 金属珪素用のゴム樹炭の生産を行うと同時に, この豊 富なゴム樹炭を原料として活性炭の製造試験を日本に 执いて実施し，工業化に成功した。

ゴム樹炭の水蒸気賦活は $1 ， 2$ の企業ですでに試み られたことがあるが詳細は不明である。本研究では 2 種類の賦活炉すなわちロータリーキルン特よびシャフ 卜炉による水蒸気賦活試験を行い, ガス賦活形式によ る操作招よび生成物の差異について検討を加光た。

\section{2. 試験装置および方法}

\section{1 水蒸気賦活装置}

ゴム樹炭の水蒸気賦活試験に用いたロータリーキル ンをFig. 1 に示した。キルン本体は外径 $0.7 \mathrm{~m} \phi$ (内 径 $0.57 \mathrm{~m} \phi$ ), 長さ $12 \mathrm{~m}$, 傾斜角 $2 / 100 \sim 4 / 100$ (可 変), 回転数 $0.3 \sim 3.0 \mathrm{rpm}$ のもの, バーナーは天然 ガス専焼型の並流式のもので水蒸気は $7 \mathrm{~kg} / \mathrm{cm}^{2}$ （ボイ ラー圧力）の圧力で师前から吹込んでいる。シャフト 忓の概要を Fig. 2 亿示した。反応塔は外径 $1 \mathrm{~m} \phi$, 高 さ $9 \mathrm{~m}$ で, 水蒸気は反応塔の最下部技よび反応塔頂部

\footnotetext{
* 技術開発部 東京都千代田区大手町 1-6-1

*** 新潟工場 新潟市太郎代山辺

*** 理工学部工業化学科 東京都千代田区神田駿河台
}

から吹込んでいる。炬内温度は空気量特よび水蒸気量 を増減することで調節し，炉内圧力は排出煙道に設け たダンパーによって調整した。

\section{2 試験方法}

本試験に供したゴム樹炭は, ジョークラッシャーに より $25 \mathrm{~mm}$ 以下に粗研し, さらにダブルロールクラ ッシャーで破砕したのち振動節でロータリーキルン用 原料木炭とシャフト炉用原料木炭飞穊分けた。原料木

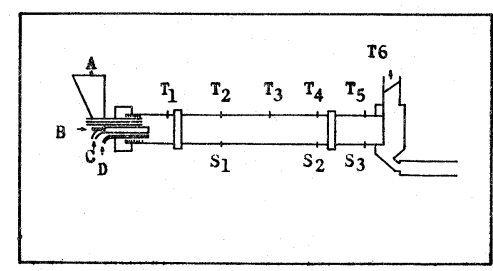

A : Charcoal, B : Natural gas, C : Air $\mathrm{D}:$ Steam, Tn : Thermocouple, $\mathrm{Sn}$ : Sampling hole

Fig. 1 Rotary kiln

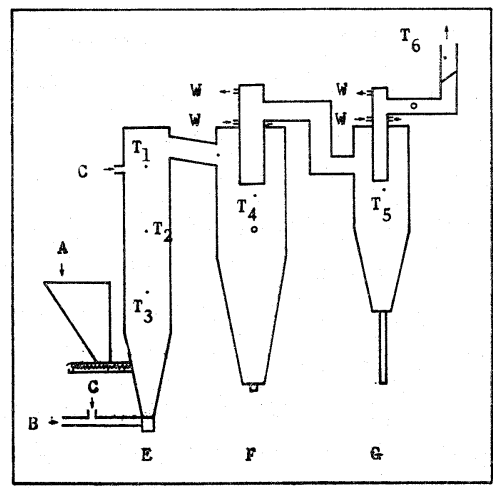

A : Charcoal, B : Air, C : Steam

$\mathrm{E}:$ Reaction furnace, $\mathrm{F}:$ No. 1 cyclone G : No. 2 cyclone, Tn : Thermocouple $\mathrm{W}$ : Cooling water

Fig. 2 Shaft furnace 
Table 1 Proximate analysis of rubber wood charcoal

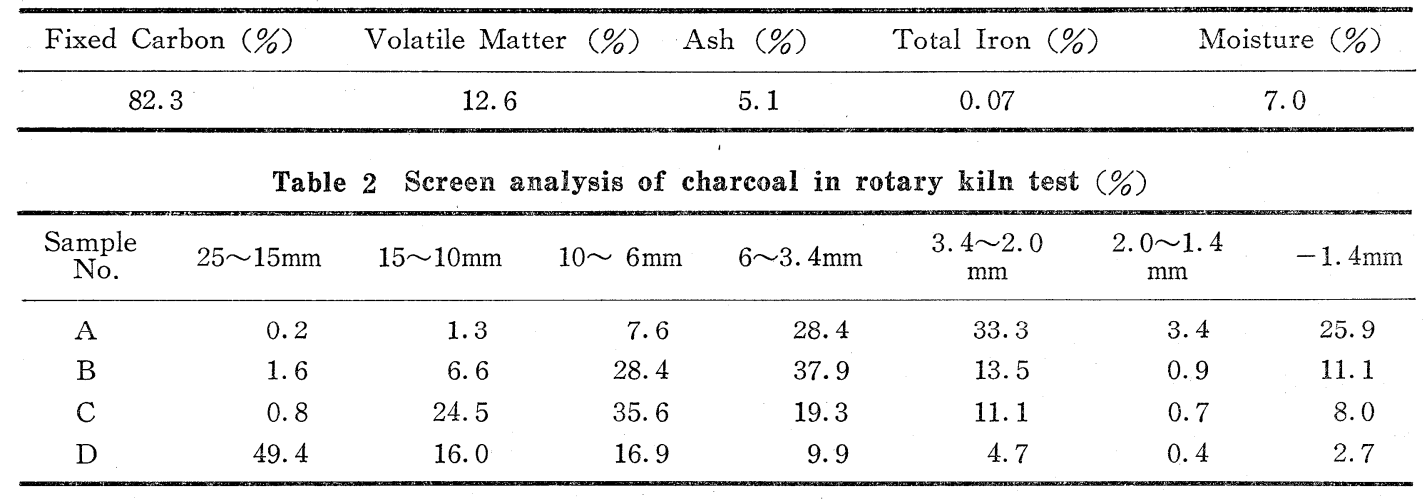

Table 3 Screen analysis of charcoal in shaft furnace test (\%)

\begin{tabular}{ccccccc}
\hline 6 9mesh & $9 \sim 16$ mesh & $16 \sim 32$ mesh & $32 \sim 48$ mesh & $48 \sim 60$ mesh & $60 \sim 80$ mesh & -80 mesh \\
\hline 2.7 & 33.2 & 35.0 & 17.0 & 5.1 & 5.1 & 1.9 \\
\hline
\end{tabular}

Table 4 Effect of retention time on the activation by rotary kiln

\begin{tabular}{|c|c|c|c|c|c|c|c|c|c|c|}
\hline \multirow{2}{*}{$\begin{array}{c}\text { Charging } \\
\text { Rate } \\
\mathrm{kg} / \mathrm{hr}\end{array}$} & \multirow{2}{*}{$\begin{array}{c}\text { Steam } \\
\text { Rate } \\
\mathrm{kg} / \mathrm{hr}\end{array}$} & \multirow{2}{*}{$\begin{array}{l}\text { Retention } \\
\text { Time } \\
\text { min. }\end{array}$} & \multicolumn{6}{|c|}{ Temperature $\left({ }^{\circ} \mathrm{C}\right)$} & \multirow{2}{*}{$\begin{array}{c}\text { Methylene } \\
\text { Blue } \\
\text { Adsorbed } \\
\text { m } \ell / g\end{array}$} & \multirow{2}{*}{$\begin{array}{r}\text { Yield } \\
\%\end{array}$} \\
\hline & & & $\mathrm{T}_{1}$ & $T_{2}$ & $T_{3}$ & $\mathrm{~T}_{4}$ & $T_{5}$ & $\mathrm{~T}_{6}$ & & \\
\hline 34.6 & 63.0 & 30 & 999 & 863 & 745 & 647 & 569 & 633 & 167 & 39.0 \\
\hline 32.8 & 61.7 & 45 & 1,002 & 864 & 750 & 654 & 574 & 637 & 166 & 40.7 \\
\hline 35.5 & 61.4 & 60 & 1,000 & 866 & 749 & 656 & 580 & 647 & 162 & 35.8 \\
\hline 34.5 & 62.7 & 90 & 999 & 868 & 750 & 668 & 596 & 658 & 169 & 32.5 \\
\hline
\end{tabular}

炭の工業分析結果と粒度分布を Table 1，2和よび 3 に示した。

$$
\text { ロータリーキルン就よびシャフト炉による賦活試験 }
$$

では, それぞれの場合について水蒸気量, 賦活温度な ぞの賦活条件が生成活性炭のメチレンブルー脱色力お よび賦活収率におよぼす影響を検討し，市わせてロー タリーキルンに付設したサンプリング孔およびキルン の排出端から採取した試料のメチレンブルー脱色力を 測定して, ロータリーキルン内に和ける賦活度の変化 を調べた。さらにロータリーキルンの長さ方向の中央 部にサイドバーナーを設置してキルン中央部の温度 $\left(\mathrm{T}_{3}\right)$ を上昇させ, 長さ $12 \mathrm{~m}$ のキルン内部全体で賦活 反応が進行するようにして, キルン内に叔ける賦活度 の変化をみた。この場合に原料木岸の炬内滞留時間 は, ロータリーキルンの回転数を調節してつぎの Warner の式によって算出した。

$$
\begin{aligned}
& \mathrm{T}= \frac{1.77 \times \sqrt{\alpha} \times \mathrm{L} \times \mathrm{F}}{\theta \times \mathrm{D} \times \mathrm{N}} \\
& \mathrm{T}: \text { 炉内滞留時間 } \quad(\mathrm{min})
\end{aligned}
$$

$$
\begin{array}{ll}
\alpha: \text { 原料木炭の安息角 } & \left(^{\circ}\right) \\
\mathrm{L}: \text { キルン有効長さ } & (\mathrm{m}) \\
\mathrm{F}: \text { 圧縮係数 } & \\
\theta: \text { キルン傾斜角 } & \left(^{\circ}\right) \\
\mathrm{D}: \text { ライニング内径 } & (\mathrm{m} \phi) \\
\mathrm{N}: \text { 回転数 } & (\mathrm{rpm})
\end{array}
$$

つぎに生成活性炭を45分間水洗し，また $2 \%$ 塩酸で 30 分間酸洗したのち60分間温水洗して, 賦活後, 水洗 後扣よび酸洗後の試料とし，それぞれの試料の性能と 灰分の組成を調ベた。試料の吸着性能は JIS K14701967 によってメチレンブルー脱色力を, JIS K14121958 によってベンゼン吸着力を，窒素吸着法によっ て比表面積を，また JIS K1474-1975 によって pH をとれぞれ測定した。

\section{3. 結果および然察}

3.1 ロータリーキルンによる賦活

3.1 .1 滞留時間の影響

本試験では Table 2, Aの粒度分布のゴム樹孷を原 料として使用した。給炭速度を $35 \mathrm{~kg} / \mathrm{hr}$, 賦活温度 
（T $T_{1}$ を $1,000^{\circ} \mathrm{C}$, 水蒸気量を $62 \mathrm{~kg} / \mathrm{hr}$ ，排出端の炉 内圧力を $0.3 \mathrm{mmAq}$ とほ汪一定として, 炬内㴆留 時間を 30〜90 min に変化させたときの試験結果を Table 4 に示した。Table 4 から，生成活性炭のメチ レンブルー脱色力は炬内滞留時間が $30 \sim 90 \mathrm{~min}$ の範 囲では 160〜170 m $/ / \mathrm{g}$ とほとんど変らないが，賦活 収率は炉内滞留時間が長い注ど低下し約39\%から33\% となった。

\section{1 .2 水蒸気量の影響}

本試験では Table 2, A，の粒度分布のゴム樹炭を 原料として使用し，給炭速度を $50 \mathrm{~kg} / \mathrm{hr}$ ，賦活温度 $\left(T_{1}\right)$ を $1,000^{\circ} \mathrm{C}$, 炉内滞留時間を $30 \mathrm{~min}$, 排出端の 炉内圧力を $0.3 \mathrm{mmAq}$ とほぼ一定として, 水蒸気量 を $50 \sim 85 \mathrm{~kg} / \mathrm{hr}$ の範团で変化させたときの試験結果 をTable 5 に示した。この結果から, 水蒸気量を増 加すると生成活性炭のメチレンブル一脱色力は 100 $\mathrm{m} \ell / \mathrm{g}$ から $167 \mathrm{~m} \ell / \mathrm{g}$ へと向上し，賦活収率は $51 \%$ から33\%へと低下した。

\subsection{3 賦活温度の影響}

本試験では Table 2, Aの粒度分布のゴム樹炭を原 料として使用し，給炭速度を $50 \mathrm{~kg} / \mathrm{hr}$ ，水蒸気量を $85 \mathrm{~kg} / \mathrm{hr}$, 炉内滞留時間を $30 \mathrm{~min}$, 排出端の炉内圧 力を $0.3 \mathrm{mmAq}$ とほぼ一定として, 賦活温度 $\left(\mathrm{T}_{1}\right)$ を $900,950,1,000^{\circ} \mathrm{C}$ に変化させて試験を行った。そ の結果を Table 6 に示した。

この結果から, 賦活温度 $\left(T_{1}\right)$ を $1,000^{\circ} \mathrm{C}$ から $900^{\circ} \mathrm{C}$ に低下させると賦活収率が34\%から52\%に増加して生 成活性炭のメチレンブルー脱色力は $167 \mathrm{~m} \ell / \mathrm{g}$ から約 $80 \mathrm{~m} \ell / \mathrm{g}$ に低下することがわかる。

\section{1 .4 原料木炭粒度の影響}

本試験では Table 2 に示した粒度分布の異なる 4 種 類のゴム樹炭を使用した。給炭速度を $35 \mathrm{~kg} / \mathrm{hr}$ ，水 蒸気量を $60 \mathrm{~kg} / \mathrm{hr}$, 賦活温度 $\left(\mathrm{T}_{1}\right)$ を $1,000^{\circ} \mathrm{C}$, 炉内 滞留時間を $30 \mathrm{~min}$ ，排出端の炉内圧力を $0.3 \mathrm{mmAq}$ とほぼ一定として，粒度の異なるゴム樹炭を賦活した ときの試験結果をTable 7 に示した。

Table 7 から，粒度が最も大きいD原料木炭を除い ては，原料木炭の粒度に関係なく生成活性炭のメチレ

Table 5 Effect of steam rate on the activation by rotary kiln

\begin{tabular}{|c|c|c|c|c|c|c|c|c|c|c|}
\hline \multirow{2}{*}{$\begin{array}{c}\text { Charging } \\
\text { Rate } \\
\mathrm{kg} / \mathrm{hr}\end{array}$} & \multirow{2}{*}{$\begin{array}{l}\text { Steam } \\
\text { Rate } \\
\mathrm{kg} / \mathrm{hr}\end{array}$} & \multirow{2}{*}{$\begin{array}{l}\text { Retention } \\
\text { Time } \\
\text { min. }\end{array}$} & \multicolumn{6}{|c|}{ Temperature $\left({ }^{\circ} \mathrm{C}\right)$} & \multirow{2}{*}{$\begin{array}{l}\text { Methylene } \\
\text { Blue } \\
\text { Adsorbed } \\
\text { m } / \mathrm{g}\end{array}$} & \multirow{2}{*}{$\begin{array}{c}\text { Yield } \\
\%\end{array}$} \\
\hline & & & $\mathrm{T}_{1}$ & $\mathrm{~T}_{2}$ & $\mathrm{~T}_{3}$ & $\mathrm{~T}_{4}$ & $T_{5}$ & $\mathrm{~T}_{6}$ & & \\
\hline 48.6 & 83.2 & 30 & 997 & 907 & 805 & 712 & 632 & 699 & 167 & 33.8 \\
\hline 48.4 & 65.8 & 30 & 1,000 & 837 & 697 & 584 & 495 & 557 & 139 & 42.1 \\
\hline 49.3 & 51.8 & 30 & 996 & 827 & 688 & 578 & 485 & 553 & 100 & 50.8 \\
\hline
\end{tabular}

Table 6 Effect of temperature on the activation by rotary kiln

\begin{tabular}{|c|c|c|c|c|c|c|c|c|c|c|}
\hline \multirow{2}{*}{$\begin{array}{c}\text { harging } \\
\text { Rate } \\
\mathrm{Ckg} / \mathrm{hr}\end{array}$} & \multirow{2}{*}{$\begin{array}{l}\text { Steam } \\
\text { Rate } \\
\mathrm{kg} / \mathrm{hr}\end{array}$} & \multirow{2}{*}{$\begin{array}{c}\text { Retention } \\
\text { Time } \\
\text { min. }\end{array}$} & \multicolumn{6}{|c|}{ Temperature $\left({ }^{\circ} \mathrm{C}\right)$} & \multirow{2}{*}{$\begin{array}{c}\text { Methylene } \\
\text { Blue } \\
\text { Adsorbed } \\
\mathrm{m} \ell / \mathrm{g}\end{array}$} & \multirow{2}{*}{$\begin{array}{l}\text { Yield } \\
\%\end{array}$} \\
\hline & & & $T_{1}$ & $\mathrm{~T}_{2}$ & $T_{3}$ & $T_{4}$ & $\mathrm{~T}_{5}$ & $\mathrm{~T}_{6}$ & & \\
\hline 45.9 & 85.2 & 30 & 896 & 812 & 698 & 605 & 519 & 560 & 81 & 52.3 \\
\hline 46.9 & 86.9 & 30 & 949 & 810 & 685 & 581 & 492 & 551 & 132 & 46.6 \\
\hline 48.6 & 83.2 & 30 & 997 & 907 & 805 & 712 & 632 & 699 & 167 & 33.8 \\
\hline
\end{tabular}

Table 7 Effect of charcoal size on the activation by rotary kiln

\begin{tabular}{|c|c|c|c|c|c|c|c|c|c|c|c|}
\hline \multirow{2}{*}{$\begin{array}{l}\text { Sample } \\
\text { No. }\end{array}$} & \multirow{2}{*}{$\begin{array}{c}\text { Charging } \\
\text { Rate } \\
\mathrm{kg} / \mathrm{hr}\end{array}$} & \multirow{2}{*}{$\begin{array}{l}\text { Steam } \\
\text { Rate } \\
\mathrm{kg} / \mathrm{hr}\end{array}$} & \multirow{2}{*}{$\begin{array}{c}\text { Retention } \\
\text { Time } \\
\text { min. }\end{array}$} & \multicolumn{6}{|c|}{ Temperature $\left({ }^{\circ} \mathrm{C}\right)$} & \multirow{2}{*}{$\begin{array}{c}\text { Methylene } \\
\text { Blue } \\
\text { Adsorbed } \\
\mathrm{m} \ell / \mathrm{g}\end{array}$} & \multirow{2}{*}{$\begin{array}{c}\text { Yield } \\
\%\end{array}$} \\
\hline & & & & $\mathrm{T}_{1}$ & $\mathrm{~T}_{2}$ & $T_{3}$ & $\mathrm{~T}_{4}$ & $T_{5}$ & $T_{6}$ & & \\
\hline $\mathrm{A}$ & 34.6 & 63.0 & 30 & 999 & 863 & 745 & 647 & 569 & 633 & 167 & 39.0 \\
\hline$B$ & 36.2 & 62.5 & 30 & 999 & 853 & 784 & 690 & 608 & 657 & 182 & 32.1 \\
\hline $\mathrm{C}$ & 34.7 & 60.5 & 30 & 999 & 843 & 751 & 651 & 551 & 628 & 165 & 40.6 \\
\hline $\mathrm{D}$ & 34.0 & 60.7 & 30 & 999 & 876 & 795 & 700 & 700 & 675 & 126 & 29.9 \\
\hline
\end{tabular}


ンブルー脱色力はほぼ 170 $180 \mathrm{~m} \ell / \mathrm{g}$ であり，また 賦活収率は約 32 4 $1 \%$ である。粒度の大きい原料木宸 $\mathrm{D}$ からの生成活性炭のメチレンブルー脱色力は 126 $\mathrm{m} \ell / \mathrm{g}$ ，その賦活収率は $29.9 \%$ となる。いずれも原料 木炭 $\mathrm{A}, \mathrm{B}, \mathrm{C}$ 比較して低い値となっている。

3.1 .5 ロータリーキルン内に和ける賦活度の变化

上述のゴム樹炭のロータリーキルンによる水蒸気賦 活試験(a)〜(d)に和いて最もよい結果が得られた条件 は, 炉内滞留時間を $30 \mathrm{~min}$, 水蒸気量を給炭速度の 約1.7倍, 賦活温度 $\left(\mathrm{T}_{1}\right)$ を $1,000^{\circ} \mathrm{C}$, 原料木炭の粒度 を $10 \mathrm{~mm}$ 以下とすることである。この条件で，給炭 速度を $35 \mathrm{~kg} / \mathrm{hr}$ と乙炬内滞留時間を 30，45，60，90 min, 飞変化させてゴム樹炭を賦活した場合, ロータ リーキルン内における賦活度の変化はFig. 3 に示すと おりである。

この場合に炉内滞留時間とは汪とんど関係なく原料 装入口から約 $8 \mathrm{~m}$ をずると师内温度が $700^{\circ} \mathrm{C}$ 以下と なり，賦活反応が進行しないので生成活性炭のメチレ

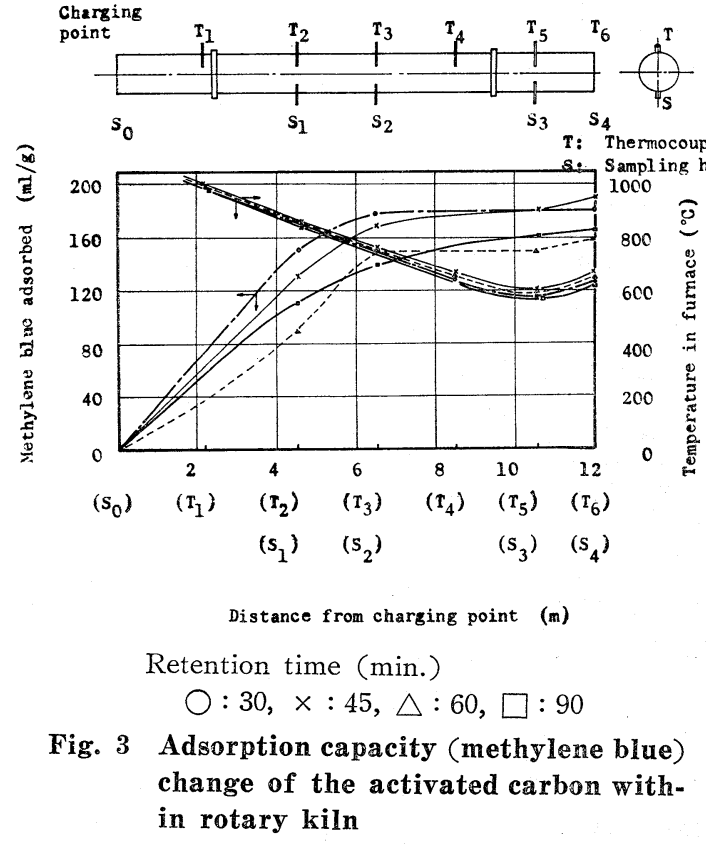

ンブルー脱色力はほぼ一定となり，賦活反応はロータ リーキルン中央部までに和いてほとんど終了してい る。また炉内滞留時間の短い方がロータリーキルン中 央部でメチレンブルー脱色力の高い活性炭が生成され る傾向がある。この原因は給炭速度が一定であるため 炬内滞留時間を短くした方が原料木炭粒の保有容積す なわらキルンの断面積に対する被処理物の面積比が小 となり，原料木炭粒が水蒸気と接触する機会が増大し て水性ガス反応が促進されるものと考えられる。

\subsection{6 サイドバーナーの影響}

前述のようにロータリーキルンの中央部から排出端 までの約 $700^{\circ} \mathrm{C}$ 以下の温度带では賦活反応が進行しな いので, キルンのほぼ中央部にサイドバーナーを付設 してキルン中央部の温度 $\left(\mathrm{T}_{3}\right)$ を $900^{\circ} \mathrm{C}$ に上昇させる ようにして賦活試験を行った。この場合の給炭速度は $50 \mathrm{~kg} / \mathrm{hr}$, 炉内滞留時間は $30 \mathrm{~min}$, 水蒸気量は 85 $\mathrm{kg} / \mathrm{hr}$ であり, ロータリーキルン内に和ける炉内温度 と賦活度の変化は Table 8 に示すと打りである。

この結果からわかるように, サイドバーナーを使用 することによって炉内最高温度を従来より $100^{\circ} \mathrm{C}$ 低い $900^{\circ} \mathrm{C}$ とし, また炉内最低温度を従来より $100 \sim 250^{\circ} \mathrm{C}$ 高い $740^{\circ} \mathrm{C}$ とてロータリーキルン内の温度差を小さ くすることにより，賦活収率を低下させることなく生 成活性炭のメチレンブルー脱色力を約 $30 \mathrm{ml} / \mathrm{g}$ 向上 させて 190〜200 ml/g とすることができた。

3.2 シャフト炉による賦活

ゴム樹炭は素灰などの他の出発原料に比較して反応 性がきわめてよいので1), 此較的炉内滞留時間の短い シャフト炉を使用しても十分な賦活反応をうけること ができると推定される。

\section{2 .1 賦活温度の影響}

給炭速度を $100 \mathrm{~kg} / \mathrm{hr}$, 水蒸気量を $100 \mathrm{~kg} / \mathrm{hr}$ とほ ぼ一定として空気量の增減により賦活温度 $\left(\mathrm{T}_{1}\right)$ を $1,100 \sim 1,150^{\circ} \mathrm{C}$ の範团に変化させて賦活試験を行い, 賦活温度が生成活性炭のメチレンブルー脱色力执よび 賦活収率に和よぼす影響を調べた。その結果をTable 9 に示したが，賦活温度 $\left(T_{1}\right)$ を $1,100^{\circ} \mathrm{C}$ か $1,150^{\circ} \mathrm{C}$

Table 8 Effect of side burner on the activation by rotary kiln

\begin{tabular}{|c|c|c|c|c|c|c|c|c|c|c|}
\hline \multirow{2}{*}{$\begin{array}{c}\text { Charging } \\
\text { Rate } \\
\mathrm{kg} / \mathrm{hr}\end{array}$} & \multirow{2}{*}{$\begin{array}{l}\text { Steam } \\
\text { Rate } \\
\mathrm{kg} / \mathrm{hr}\end{array}$} & \multirow{2}{*}{$\begin{array}{l}\text { Retention } \\
\text { Time } \\
\text { min. }\end{array}$} & \multicolumn{6}{|c|}{ Temperature $\left({ }^{\circ} \mathrm{C}\right)$} & \multirow{2}{*}{$\begin{array}{c}\text { Methylene } \\
\text { Blue } \\
\text { Adsorbed } \\
\mathrm{m} \ell / \mathrm{g}\end{array}$} & \multirow{2}{*}{$\begin{array}{c}\text { Yield } \\
\%\end{array}$} \\
\hline & & & $T_{1}$ & $\mathrm{~T}_{2}$ & $\mathrm{~T}_{3}$ & $\mathrm{~T}_{4}$ & $\mathrm{~T}_{5}$ & $\mathrm{~T}_{6}$ & & \\
\hline 53.4 & 85 & 30 & 1,000 & 946 & 896 & 811 & 706 & 744 & 160 & 26.2 \\
\hline 53.4 & 85 & 30 & 954 & 875 & 918 & 845 & 736 & 773 & 193 & 34.2 \\
\hline 53.4 & 85 & 30 & 900 & 840 & 900 & 838 & 740 & 769 & 193 & 39.0 \\
\hline
\end{tabular}


飞上昇させると，生成活性炭のメチレンブルー脱色力 は $131 \mathrm{~m} \ell / \mathrm{g}$ が $157 \mathrm{~m} \ell / \mathrm{g}$ と高くなるが賦活收率は 18.4\%が13.6\%に低下することがわかった。

一般にシャフト炉では流動層形式で木炭粒の炉内滞 留時間が短いのが特徵で，使用される原料木炭の粒度 はロータリーキルン用原料木炭の粒度に比較して小さ く，さらにシャフト炉内に和いて原料木炭り一部を自 然させながら必要な熱量を供給するので1)2)3)，生成活 性炭の賦活収率はロータリーキルンの場合に比較して 低い値となる。

つぎに賦活温度 $\left(T_{1}\right)$ が $1,120^{\circ} \mathrm{C}$ で得た生成活性炭 の粒度分布，粒度別の死分量とメチレンブルー脱色力 をTable10に示した。上述のようにシャフト炉では原 料木炭の一部を自然させているので, 原料木炭の燃焼 残渣である死分が生成活性炭中に含をれ，その灰分量 法16.4\% と非常に多い。また生成活性炭の粒度別灰分 量は粒度が小さくなるほど多くなり，そのために生成 活性炭のメチレンブルー脱色力は低くなっている。

3.2 .2 水蒸気量の影響
本試験では水蒸気量を減じ，できるだけ少ない空気 量で操業して賦活収率を向上させるよう試験を実施し た。給炭速度を $100 \mathrm{~kg} / \mathrm{hr}$ ，賦活温度 $\left(\mathrm{T}_{1}\right)$ を 1,120 ○と泀ぼ一定として, 水蒸気量を $100 \sim 22 \mathrm{~kg} / \mathrm{hr}$ の範 囲で変化させて賦活した試験結果を Table 11 に示し た。

この試験結果は, 水蒸気量を $100 \mathrm{~kg} / \mathrm{hr}$ から 40 $\mathrm{kg} / \mathrm{hr}$ に減じても生成活性炭のメチレンブルー脱色力 は $145 \mathrm{~m} l / \mathrm{g}$ と医とんど変化しないが，賦活収率は直 線的に向上する傾向を示している。しかし水蒸気量が $40 \mathrm{~kg} / \mathrm{hr}$ 以下になると賦活収率は急上昇し, 生成活 性炭のメチレンブルー脱色力は若干低下した。

これらの結果から, 生成活性炭のメチレンブルー脱 色力を低下させないで比較的高い賦活収率を得るに は，水蒸気量は $30 \sim 40 \mathrm{~kg} / \mathrm{hr}$ すなわち給炭速度の約 0.4 倍が適当であると考学られる。

\section{2 .3 給炭速度の影響}

水蒸気量を $30 \mathrm{~kg} / \mathrm{hr}$ ，賦活温度 $\left(\mathrm{T}_{1}\right)$ を $1,120^{\circ} \mathrm{C}$ と 添ぼ一定として，給炭速度を 100〜140 kg/hr の範困

Table 9 Effect of temperature on the activation by shaft furnace

\begin{tabular}{|c|c|c|c|c|c|c|c|c|c|c|}
\hline \multirow{2}{*}{$\begin{array}{c}\text { Charging } \\
\text { Rate } \\
\mathrm{kg} / \mathrm{hr}\end{array}$} & \multirow{2}{*}{$\begin{array}{l}\text { Steam } \\
\text { Rate } \\
\mathrm{kg} / \mathrm{hr}\end{array}$} & \multirow{2}{*}{$\begin{array}{l}\text { Air Rate } \\
\mathrm{Nm}^{3} / \mathrm{hr}\end{array}$} & \multicolumn{6}{|c|}{ Temperature $\left({ }^{\circ} \mathrm{C}\right)$} & \multirow{2}{*}{$\begin{array}{c}\text { Methylene } \\
\text { Blue } \\
\text { Adsorbed } \\
\text { m } \ell / g \\
\end{array}$} & \multirow{2}{*}{$\begin{array}{c}\text { Yield } \\
\%\end{array}$} \\
\hline & & & $T_{1}$ & $\mathrm{~T}_{2}$ & $\mathrm{~T}_{3}$ & $\mathrm{~T}_{4}$ & $T_{5}$ & $\mathrm{~T}_{6}$ & & \\
\hline 107.2 & 100 & 450 & 1,147 & 1,065 & 816 & 516 & 304 & 310 & 157 & 13.6 \\
\hline 98.1 & 100 & 420 & 1,123 & 1,070 & 830 & 548 & 352 & 352 & 144 & 16.2 \\
\hline 97.3 & 100 & 408 & 1,100 & 1,055 & 821 & 548 & 349 & 348 & 131 & 18.4 \\
\hline
\end{tabular}

Table 10 Properties of activated carbon by shaft furnace

\begin{tabular}{lccccccc}
\hline Grain Size (mesh) & $9 \sim 16$ & $16 \sim 32$ & $32 \sim 48$ & $48 \sim 60$ & $60 \sim 80$ & -80 & Average \\
\hline Screen Analysis (\%) & 1.4 & 49.9 & 23.0 & 5.9 & 8.2 & 11.6 & - \\
Ash (\%) & 8.0 & 10.1 & 12.4 & 17.4 & 21.3 & 48.3 & 16.4 \\
Methylene Blue & 160. & 160. & 130. & 120. & 130. & 90. & 145. \\
$\quad$ Adsorbed (ml/g) & & &
\end{tabular}

Table 11 Effect of steam rate on the activation by shaft furnace

\begin{tabular}{|c|c|c|c|c|c|c|c|c|c|}
\hline \multirow{2}{*}{$\begin{array}{c}\text { Charging } \\
\text { Rate } \\
\mathrm{kg} / \mathrm{hr}\end{array}$} & \multirow{2}{*}{$\begin{array}{l}\text { Steam } \\
\text { Rate } \\
\mathrm{kg} / \mathrm{hr}\end{array}$} & \multirow{2}{*}{$\begin{array}{l}\text { Air Rate } \\
\mathrm{Nm}^{3} / \mathrm{hr}\end{array}$} & \multicolumn{5}{|c|}{ Temperature $\left({ }^{\circ} \mathrm{C}\right)$} & \multirow{2}{*}{$\begin{array}{c}\text { Methylene } \\
\text { Blue } \\
\text { Adsorbed } \\
\mathrm{m} \ell / \mathrm{g}\end{array}$} & \multirow{2}{*}{$\begin{array}{c}\text { Yield } \\
\%\end{array}$} \\
\hline & & & $\mathrm{T}_{1}$ & $\mathrm{~T}_{2}$ & $\mathrm{~T}_{3}$ & $T_{4}$ & $T_{5}$ & & \\
\hline 98.1 & 100.0 & 420 & 1,123 & 1,070 & 830 & 548 & 352 & 144 & 16. 2 \\
\hline 98.8 & 72.5 & 372 & 1,120 & 1,019 & 784 & 513 & 312 & 146 & 18.5 \\
\hline 91.9 & 53.9 & 360 & 1,119 & 992 & 762 & 500 & 276 & 138 & 19. 7 \\
\hline 97.0 & 37.0 & 330 & 1,119 & 972 & 759 & 492 & 260 & 143 & 21.9 \\
\hline 101.2 & 27.3 & 309 & 1,123 & 977 & 640 & 508 & 278 & 139 & 25.5 \\
\hline 95.7 & 21.7 & 299 & 1,119 & 960 & 629 & 479 & 250 & 133 & 25.9 \\
\hline
\end{tabular}


Table 12 Effect of charging rate on the activation by shaft furnace

\begin{tabular}{|c|c|c|c|c|c|c|c|c|c|c|}
\hline \multirow{2}{*}{$\begin{array}{c}\text { Charging } \\
\text { Rate } \\
\mathrm{kg} / \mathrm{hr}\end{array}$} & \multirow{2}{*}{$\begin{array}{l}\text { Steam } \\
\text { Rate } \\
\mathrm{kg} / \mathrm{hr}\end{array}$} & \multirow{2}{*}{$\begin{array}{c}\text { Air } \\
\text { Rate } \\
\mathrm{Nm}^{3} / \mathrm{hr}\end{array}$} & \multicolumn{5}{|c|}{ Temperature $\left({ }^{\circ} \mathrm{C}\right)$} & \multirow{2}{*}{$\begin{array}{c}\text { Ash } \\
\%\end{array}$} & \multirow{2}{*}{$\begin{array}{l}\text { Methylene } \\
\text { Blue Adso- } \\
\text { rbed m } \boldsymbol{l} / \mathrm{g}\end{array}$} & \multirow{2}{*}{$\begin{array}{c}\text { Yield } \\
\%\end{array}$} \\
\hline & & & $T_{1}$ & $\mathrm{~T}_{2}$ & $T_{3}$ & $\mathrm{~T}_{4}$ & $T_{5}$ & & & \\
\hline 143.7 & 33.7 & 372 & 1,117 & 1,007 & 680 & 563 & 357 & 8.5 & 116 & 36.8 \\
\hline 126.7 & 30.6 & 348 & 1,118 & 996 & 663 & 532 & 318 & 9.5 & 139 & 31.5 \\
\hline 117.1 & 31.1 & 311 & 1,121 & 968 & 643 & 503 & 283 & 11.0 & 138 & 27.9 \\
\hline 101. 2 & 27.3 & 309 & 1,123 & 977 & 640 & 508 & 278 & 12.3 & 139 & 25.5 \\
\hline
\end{tabular}

Table 13 Properties of activated carbon after water-washing \& acid-washing

\begin{tabular}{|c|c|c|c|c|c|c|c|c|c|}
\hline \multirow[t]{2}{*}{ Activated Carbon } & \multirow{2}{*}{$\begin{array}{c}\text { Methylene } \\
\text { Blue } \\
\text { Adsorbed } \\
\mathrm{m} \ell / \mathrm{g}\end{array}$} & \multirow{2}{*}{$\begin{array}{c}\text { Benzene } \\
\text { Adsorbed } \\
\%\end{array}$} & \multirow{2}{*}{$\begin{array}{c}\text { Specific } \\
\text { Surface } \\
\text { Area } \\
\mathrm{m}^{2} / \mathrm{g}\end{array}$} & \multirow{2}{*}{$\begin{array}{c}\mathrm{pH} \\
-\end{array}$} & \multirow{2}{*}{$\begin{array}{c}\text { Ash } \\
\%\end{array}$} & \multicolumn{4}{|c|}{$\begin{array}{c}\text { Chemical Composition } \\
\text { of Ash } \%\end{array}$} \\
\hline & & & & & & $\mathrm{SiO}_{2}$ & $\mathrm{Al}_{2} \mathrm{O}_{3}$ & $\mathrm{CaO}$ & $\mathrm{K}_{2} \mathrm{O}$ \\
\hline After Activation & 170 & 34.7 & 980 & 10.7 & 9.09 & 8.5 & 1. 4 & 44.0 & 20.2 \\
\hline $\begin{array}{l}\text { After Water- } \\
\text { Washing }\end{array}$ & 165 & 34.7 & - & 10.1 & 6.50 & 9.6 & 2.4 & 50.4 & 7.4 \\
\hline $\begin{array}{c}\text { After Acid- } \\
\text { Washing }\end{array}$ & 190 & 38.8 & 一 & 7.1 & 3.04 & 21.2 & 9.0 & 27.2 & 5.5 \\
\hline
\end{tabular}

で変化させて賦活した試験結果をTable 12に示した。

この結果によると給炭速度が $100 〜 127 \mathrm{~kg} / \mathrm{hr}$ の範 国では，給炭速度が増大すると生成活性炭のメチレン ブルー脱色力は 138〜 $139 \mathrm{ml} / \mathrm{g}$ とほぼ一定であるの に賦活収率は $25.5 \%$ か $31.5 \%$ と向上し，また生成活 性炭中の灰分量も $12.3 \%$ から $9.5 \%$ と低下する傾向を 示している。これは給炭速度の増大率に対して空気量 の増大率が若干低く，その結果として原料木炭の燃焼 率が低下して賦活収率を向上させたものと考光られ る。

\subsection{4 ロータリーキルンによる賦活との比較}

上述の試験操業の結果から，ゴム樹炭を出発原料と するロータリーキルンとシャフト炉による活性崖製造 における得失を比較すると，つぎのようになる。

(1)ロータリーキルンは反応性のわるい比較的粒度の大 きい木炭粒を使用し，処理温度を比較的低く炉内滞 留時間を長く保持しながら賦活したい場合によい。 この場合に賦活炉の操業管理は比較的容易であるが 建設費が高くなる欠点がある。

シャフト炉は炉内滞留時間が比較的短いのでゴム 樹炭のように反応性のよい比較的粒度の小さい木炭 粒を使用し，処理温度を比較的高く保持しながら賦 活したい場合によい。この場合には賦活炉の操業管 理に熟練を要するが建設費は安い。

(ロ)3.1のロータリーキルンによる賦活の場合には天然 ガスを熱源に使用しているが， 3.2 のシャフト炉に よる賦活の場合には天然ガスを熱源に使用しないで
原料木炭粒の一部を自然させている。したがって， 理論的にはシャフト炻の場合でも天然ガスを熱源と して利用すれば, ロータリーキルンの場合と同様に 賦活収率を高めることができるはずである。天然が スと原料木炭の然料源としての価格によっていずれ かを選定することになる。

3.3 生成活性炭の水洗および酸洗後の性質と 灰分の組成

ロータリーキルンによって賦活したゴム樹活性炭の 賦活後, 水洗後执よび酸洗後の性質之灰分の組成を Table 13に示した。この結果からゴム樹活性炭は水洗 または酸洗により活性炭含有の不純物が除去され，十 分に精製することができ活性炭のメチレンブルー脱色 力が向上することがわかる。

\section{4. 結言}

ゴム樹炭をロータリーキルンおよびシャフト炉によ り水蒸気賦活した操業結果を比較して, メチレンブル 一脱色力 $160 \mathrm{ml} / \mathrm{g}$ 以上の活性炭を製造する条件をそ れぞれの賦活形式に対して試験研究した。

サイドバーナーを付設していないロータリーキルン では，炉内滞留時間は $30 \mathrm{~min}$ ，水蒸気量は給炭速度 (原料装入量) の約 1.7 倍, 賦活温度 $\left(T_{1}\right)$ は, 1,000 ${ }^{\circ} \mathrm{C}$ ，原料木炭の粒度は $10 \mathrm{~mm}$ 以下が適当で，そのと きの賦活収率は約34～39\%である。この場合，賦活区 応はキルンの原料装入口から中央部 (炉内温度 : 約 $700^{\circ} \mathrm{C}$ ) までに洼とんど終了し，中央部から排出端ま での $700^{\circ} \mathrm{C}$ 以下の低温度帯では賦活反応はほとんど進 
行しない。このためキルン内の広、範囲にわたり賦活 反応が進行するように，キルンの汪涪中央にサイドバ ーナーを付設し炬内の 最高温度を $900^{\circ} \mathrm{C}$, 最低温度を $740^{\circ} \mathrm{C}$ になるよらにキルン内の温度差を小さくした結 果, 賦活收率を低下させることなく生成活性炭のメチ レンブルー脱色力を約 $30 \mathrm{~m} / / \mathrm{g}$ 向上させて 190〜200 $\mathrm{m} \ell / \mathrm{g}$ とすることができた。

シャフト炉では原料木炭の粒度が 12〜80 mesh の 場合, 賦活温度は $1,120^{\circ} \mathrm{C}$, 水蒸気量は給炭速度の約 0.4 倍が適当である。そのときの生成活性炭のメチレ ンブルー脱色力は約 $140 \mathrm{~m} \ell / \mathrm{g}$, 賦活収率は 25〜30\%
である。また生成活性炭中の灰分量は約16\%でロータ リーキルンによって賦活した生成活性炭に比較して非 常に多量であるが，水洗扣よび酸洗によって灰分の大 半は除去され, 生成活性炭のメチレンブルー脱色力む $160 \mathrm{~m} \ell / \mathrm{g}$ 以上飞向上する。

\section{文献}

1) 柳井 弘 : 化学工学, 18, 81 (1954)； 26, 1089 (1962); 26, 519 (1962)

2) 柳井弘注か：日特第178584 (Apr. 1949)

3）柳井 弘：燃協講演 (Aug. 1953)

\title{
Studies on the Manufacture of Activated Carbon for Liquid Phase from the Rubber Wood Charcoal
}

\author{
Masami Hirose*, Kunio KAWAWAdA*, \\ Hiroyuki AOKI* and Hiroshi YANAI** \\ (*Pacific Metals Co., Ltd. **Nihon University)
}

SYNOPSIS : - A basic study on producing activated carbon from the rubber wood charcoal using both a rotary kiln and a shaft furnace was performed, and the following results were obtained.

(1) As the operation conditions for producing activated carbon with a decoloring power of over $160 \mathrm{~m} \ell / \mathrm{g}$ for Methylene Blue solution, $1000^{\circ} \mathrm{C}$ of activation temperature, $30 \mathrm{~min}$. of retention time and steam-char ratio of approx. 1.7, granular size of charcoal smaller than $10 \mathrm{~mm}$ are suitable for the rotary kiln, and under such conditions the yield is about $34-39 \%$.

(2) As the result of installation of a side burner around lengthwise middle of the rotary kiln to decrease temperature gradient, decoloring power of produced activated carbon is increased to $190-200 \mathrm{ml} / \mathrm{g}$ for Methylene Blue solution without decreasing the yield.

(3) As the operation conditions for producing activated carbon, charcoal granular size $12-$ 80 mesh, activation temperature $1120^{\circ} \mathrm{C}$, steam-char ratio approx. 0.4 are suitable for the shaft furnace, and the yield is $25-30 \%$. Decoloring power of produced activated carbon is approx. $140 \mathrm{~m} / / \mathrm{g}$ for Methylene Blue solution, but the power can be increased to more than $160 \mathrm{~m} \ell / \mathrm{g}$ by water and acid washing to remove most of ash. 